\title{
Desain Bimbingan dan Konseling Tujuan Hidup Remaja Pelaku Klitih Melalui Metode Konseling Eksistensial
}

\author{
Sinta Pitaloka \\ Bimbingan dan Konseling Islam, Universitas Islam Negeri Sunan Kalijaga, Indonesia \\ Email :pitalokasinta90@gmail.com
}

\begin{abstract}
Abstrak. Bagi remaja, eksistensi adalah suatu proses yang dinamis dan komples, lewat memilih, menilai, menerima dan menolak manusia konstan menjadi (becoming) sesuatu yang berbeda daripada sebelumnya. Maraknya kasus klitih yang dilakukan oleh remaja saat ini adalah salah satu akibat dari eksistensi yang mereka coba lakukan. Penelitian ini meneliti tentang desain bimbingan dan konseling remaja pelaku klitih dalam menentukan tujuan hidup melalui konseling eksistensial. Penelitian ini menggunakan penelitian kualitatif yaitu dengan studi pustaka atau riset kepustakaan. Dengan metode konseling eksistensial remaja dapat mengeksplorasi kemampuan yang dimilikinya, memahami tentang diri sendiri dan bagaimana ia ada didunia. Sehingga remaja dapat mencari makna dalam hidup, menciptakan identitas pribadiya, dan menciptakan hubungan yang bermakna dengan orang lain namun tetap dalam batasan dan kebebasan.
\end{abstract}

Kata kunci: Konseling, Remaja, Klitih

\begin{abstract}
For adolescents, existence is a dynamic and complex process, through choosing, evaluating, accepting and rejecting a constant human being (becoming) something different than before. The rise of klitih cases committed by adolescents today is one result of the existence they are trying to do. This research examines the guidance and counseling design of young actors in determining the purpose of life through existential counseling. This study uses qualitative research, namely literature study or library research. With the existential counseling method, adolescents can explore their abilities, understand about themselves and how they exist in the world. So adolescents can look for meaning in life, create their personal identity, and create meaningful relationships with others while remaining within limits and freedom
\end{abstract}

Keywords: Counselng, Adolescent, Klitih

\section{PENDAHULUAN}

Beberapa waktu ini, Yogyakarta sedang dirisaukan dengan pelaku anarkisme atau klitih yang dilakukan remaja di Yogya. Tribunjogja.com memberitakan tanggal 4 Januari 2019 kemarin, Tim Gabungan Polda DIY dan Polres Sleman berhasil menangkap 4 palaku klitih yang beraksi di 5 lokasi di Kabupaten Sleman. Kempat pelaku adalah GO
(19) berperan sebagai eksekutor, RS (16), AJ (17) dan AWR (17) tahun, dan keempatnya berstatus pelajar. Mereka tertangkap setelah tanggal 29 Desember 2018 kemarin melakukan pembacokan tanpa motif atau acak dengan menggunakan senjata tajam clurit. Selama tahun 2018 saja, tribunjogja.com memberitakan ada 13 kasus klitih dijogja, dan dua orang dinyatakan meninggal dunia. Dengan rincian diKabupaten Bantul 3 kasus, Sleman 4 Kasus, 
Kota Yogya 3 kasus, dan Gunung kidul 1 kasus. Dari beberapa pelaku yang tertangkap, mereka berusia rentang 16 hingga 19 tahun, bahkan ada yang masih 9 tahunan.

Usia 16 hingga 19 tahun menurut Wirawan (2016) tergolong dalam usia remaja. Usia remaja adalah perubahan dari anak-anak kedewasa, secara psikologis menjadi dewasa itu ketika seseorang telah mampu mengubahkan perasaan egosentrisme menjadi perasaan ikut memiliki (extension of the self), mampu melihat diri secara objektif dengan memiliki kemampuan untuk menilai dirinya sendiri dan memiliki falsafah hidup tertentu (Allport dalam Wirawan 2016).

Perilaku Klitih yang dilakukan termasuk dalam kategori kenakalan remaja dan tergolong perilaku menyimpang. Para pelaku klitih melakukan tindakannya hanya untuk bersenangsenang saja, tidak ada barang yang diambil dari korbannya. Mereka melakukan pengejaran, pelemparan batu maupun pembacokan kepada orang yang tidak dikenal, tanpa motif apapun. Remaja di usianya memiliki sebuah pemaknaan mengenai siapa dirinya dan yang membedakan dengan orang lain. Eksplorasi mengenai diri dimulai dari pemahaman tentang dirinya, kemudian berlanjut tentang harga diri dan konsep diri. Remaja yang sedang dalam proses memahami dirinya atau self-understanding sangat dipengaruhi oleh peran dan jenis keanggotaannya yang mereka ikuti (Harter dalam Santrock, 2007).

Harian merdeka.com pernah mewawancarai mantan pelaku klitih, dari pengakuannya ia menjadi seorang geng motor berawal dari hutang budi karena ditolong kakak kelasnya saat dia pernah dikeroyok pelajar sekolah lain. Setelah menjadi korban ia kemudian menceburkan diri menjadi geng pelajar di sekolahnya. Dalam geng tersebut berisi 30 orang siswa kelas 1. Mereka dites mental dan fisiknya agar dapat menjaga kehormatan sekolah dan gengnya. Mereka juga diajari cara dan metode klitih kelawannya. Target mereka hanya anggota geng yang menjadi musuh lawannya, selain itu tidak. Dijelaskan juga mereka jarang sekali menggunakan senjata tajam, jikapun menggunakan itu hanya untuk menakuti lawannya saja. Tujuan dari klitih ini hanya untuk menunjukkan eksistensi geng saja, juga untuk mengangkat nama geng agar semakin ditakuti dan disegani musuh.
Berdasarkan cerita mantan pelaku klitih tersebut dapat ditangkap bagaimana pengaruh konformitas atau kelompok mampu memperngaruhi perilaku remaja. Hal ini juga telah dibuktikan dengan penelitian dari Hidayati (2016) menunjukkan adanya korelasi antara harga diri, konformitas teman sebaya dengan kenakalan remaja. Penelitian lain dilakukan oleh Prayugo, Suroso dan Meiyutaringsih (2018) yaitu dapat disimpulkan bahwa konformitas teman sebaya memiliki kontribusi terhadap variabel perilaku agresif. Apabila semakin tinggi konformitas teman sebaya pada remaja maka akan rendah perilaku agresifnya, begitu juga sebaliknya. Novianti, Abdul Munir dan Munifah (2017) juga menjelaskan bahwa ada hubungan positif antara Perilaku Konformitas Negatif Teman Sebaya dengan kenakalan remaja.

Remaja dalam upayanya memahami dirinya sendiri, sering kali berbenturan dengan relasi dan peran sosialnya. Gambaran tentang dirinya dapat berbeda tergantung ia sedang berada siapa dan sedang berperan sebagai apa. Remaja tidak saja mencoba memaknai dirinya sendiri namun juga mendeskripsikan tentang konsep dirinya dan harga dirinya.

Konsep diri mengacu pada pemahaman yang menyangkut pada bidang-bidang tertentu terkait dirinya. Sedangkan harga diri mengacu pada evaluasi diri yang bersifat global. Ketika remaja merasakan rendahnya harga dirinya, mereka akan mengalami masalah. Harga diri yang rendah dapat menyebabkan beberapa masalah salah satunya adalah kenakalan remaja. Seberapa parah permasalahan yang dapat ditimbulkan tergantung dengan kondisi lainnya. Susan Harter (dalam Santrock, 2007) mendiskripsikan remaja yang terlibat pembunuhan dan mengalami gangguan makan mempunyai penilaian terhadap harga diri yang rendah. Dalam studi laen (Harter dan McCarley dalam Santrock, 2007) mengatakan bahwa tingginya narsisme, rendahnya empati, dan kepekaan terhadap penolaakan, bersama dengan harga diri yang rendah, sangat berkaitan dengan pikiran-pikiran bengis yang ada pada remaja. Studi laennya menjelaskan bahwa remaja yang memiliki pikiran-pikiran yang begis memperlihatkan harga diri yang fluktuatif, dengan kecenderungan lebih untuk memiliki msalah perilaku, dan memiliki sejarah yang memalukan yang mengancam ego mereka (McCarley dan Harter dalam Santrock, 2007).

Konsep diri dan harga diri akan membentuk indentitas pada diri seseorang. 
Diusia remaja, pertanyaan tentang "Siapa saya" mulai dipertanyakan. Pertanyaan-pertanyaan mengenai diri sangat penting bagi perkembangan remaja. Dapat menjawab sebuah pertanyaan "Siapakah saya?" "apa yang saya inginkan?" "apakah saya berhak menilai diri saya sendiri?", merupakan tujuan dan hakikat hidup seseorang. Sebagai manusia ada pertanyaan dalam diri mengenai siapa saya, orang lain dan dunia. Konseling Eksistensial mencoba menelaah tujuan hidup seseorang yang dimulai dari menjawab pertanyaan "siapa saya", "apakah saya berhak untuk menjawab semua pertanyaan itu?", "apakah saya mengenal diri saya sendiri?",dan seterusnya. Dilema yang terjadi pada diri remaja tentang memahami siapa dirinya, memandang dirinya berlaku sebagai subjek ataupun objek diwaktu yang sama. Bagi remaja, eksistensi adalah suatu proses yang dinamis dan komples, lewat memilih, menilai, menerima dan menolak manusia konstan menjadi (becoming) sesuatu yang berbeda daripada sebelumnya.

Maka Peneliti akan meneliti tentang bagaimana konseling eksistensial digunakan untuk melakukan bimbingan dan konseling pada remaja pelaku klitih agar dapat menetukan tujuan hidupnya. Penelitian ini menggunakan penelitian kualitatif dengan metode induktif. Hal ini dilakukan karena penelitian ini menitik beratkan pada kajian atau analisis konseptual yang menitik beratkan pada pemikiranpemikiran dan bagaimana pemikiran tersebut dapat direalisasikan. Sehingga penelitian ini menggunakan studi pustaka atau riset kepustakaan, yang menitik beratkan pada bukubuku yang berkaitan dengan remaja dan teori konseling psikologi eksistensial.

\section{Remaja dan Permasalahannya}

Konseling terhadap remaja dimulai dengan memahami tahap perkembangan usia remaja. Remaja menurut WHO (dalam Wirawan, 2016) adalah saat dimana individu mampu berkembang dari saat pertama kali ia menunjukkan tanda-tanda seksualnya sampai ia mencapai kematangan seksual. Individu mengalami perkembangan psikologis dan pola identifikasi dari kanak-kanak menjadi dewasa. Dan terjadi peralihan dari ketergantungan sosialekonomi yang penuh kepada keadaan yang relatif lebih mandiri. Menurut Wirawan (2016), berdasarkan iklim remaja diIndonesia yang terdiri dari berbagai mcam sus, adat dan tingkat dodsial-ekonomi maupun pendidikan, dan dengan beberapa pertimbangan lainnya, usia remaja di Indonesia berada dibatasan usia 11 24 tahun.

Dalam perkembangan psikologis remaja akhir usia 16-19 tahun beberapa ahli menjelaskan tahap ini adalah tahapan remaja menjadi pribadi yang egosentris atau mementingkan dirinya sendiri dibanding kepentingan orang lain. Dan lebih cenderung mementingkan harga dirinya sendiri. Perubahan fisiologis, seksual dan emosional yang dirasakan remaja menjadikan sebuah tantangan tersendiri bagi mereka. Mereka meyakini bahwa tidak seorangpun dapat memahami dan mengerti mereka. Sehingga remaja merasa tertekan dengan harapan sosial atau masyarakat dan orangtuanya.

Beberapa lingkungan yang dapat berpotensi menimbulkan permasalahan berupa stres pada remaja menurut Gerrald (2011) meliputi:

\section{Lingkungan keluarga}

Sejumlah faktor dalam lingkungan keluarga yang dapat menimbulkan stres pada remaja antara lain meliputi gaya berfungsinya keluarga, gaya pengasuhan, hubungan orang tua, perpisahan dan perceraian, masalah penyatuan dua keluarga, memiliki orang tua yang alkoholik, kekerasan domestik, masalah-masalah kulturasi.

Keluarga sangat berperan dalam proses perkembangan remaja. Keluarga yang memiliki ikatan emosional yang baik memberikan kondiri lingkungan terbaik bagi tumbuh kembang pertumbuhan remaja. Keluarga yang terlalu overprotektik justru membentuk remaja menjadi pribadi yang tertekan, karena remaja merasa tidak bebas dan haknya terampas. Namun keluarga yang terlalu longgar seperti tidak banyak terlibat dalam aktivitas sehari-hari, nampak seolah tidak perduli dengan anaknya, sehingga anak menjadi lebih parah dalam melakukan aktivitasnya diluar rumah.

Nindya dan Margaretha (2012) menelaah hubungan antara kekerasan emosional dengan kecenderungan kenakalan remaja. Namun dari koefisien korelasi yang ditelitinya lemah, sehingga dapat dikatakan bahwa kekerasan hanya sebagian kecil dari faktor yang menyebabkan timbulnya perilaku kenakalan pada remaja. Faktor lain adalah kepercayaan orang tua terhadap anaknya Fatchurahman dan Pratikto (2012) meniliti bahwa terdapat korelasi negatif antara kepercayaan diri dengan 


\section{1 | JURKAM: Jurnal Konseling Andi Matappa Vol 4, No 1, Februari 2020}

kenakalan remaja. Makin tinggi kepercayaan diri remaja, makin berkurang kenakalan mereka. Mantiri, dan Andriani (2012) menilai selain persepsi mengenai pola asuh otoriter orang tua, konformitas juga memiliki pengaruh yang terhadap kenakalan remaja.

\section{Lingkungan pendidikan}

Remaja akan mengalami berbagai tekanan disekolah dan kuliah, sehingga menyebabkan stresor tersendiri bagi mereka. Dan beberapa dari mereka memilih untuk tidak bersekolah sebagai cara terbaik untuk menghindari stresornya. Jika anak enggan atau tidak mau bersekolah justru dapat menyebabkan masalah disfungsi jangka panjang jika segera ditangani.

\section{Lingkungan kerja}

Beberapa remaja bekerja paruh waktu sambil sekolah, hal ini justru menyebabkan remaja lebih memilih meninggalkan sekolahnya dan bekerja. Padahal dunia kerja adalah tempat dimana perilaku orang dewasa lebih dibutuhkan.

\section{Perubahan hubungan}

Ketika seorang anak berubah menjadi remaja, hubungan dengan orang terdekat akan mengalami perubahan, terutama dengan mereka yang memegang otoritas kehidupan mereka seperti orang tua. Orang tua perlu memahami bahwa usia remaja telah mampu mengemban tanggung jawab tertentu sehingga orang tua tidak dapat lagi mengontrol mereka seperti saat usia anak-anak. Terjadi pertentangan antara remaja yang menginginkan kontrol lebih terhadap dirinya dengan orang tua yang merasa remaja belum mampu membuat keputusan dan belum dapat melepas secepat yang dikehendaki remaja. Diusia remaja, ketertarikan seksual juga masih bersifat sementara karena mereka masih dalam tahap eksplorasi dan eksperimen. Ketika remaja memiliki perasaan cinta yang kuat dengan seseorang namun terjadi penolakan, maka akan merasa harga dirinya rendah.

5. Mengalami masalah seputar seksualitas

Beberapa daerah menunjukkan perbedaan budaya mengenai perilaku seks, pada budaya tertentu masih membatasi perilaku seksual sebelum menikah namun ada budaya yang membolehkan perilaku tersebut tentu saja dengan batasan-batasan tertentu dan resikoresiko tertentu. Al-Mighwar (2006) menjelaskan tekanan sosial terutama minat seks dan pengetahuan tentang seks mendorong remaja untuk menjalin berbagai hubungan yang baru dan lebih matang dengan lawan jenis. Karena minat seks yang semakin meningkat, remaja selalu berusaha mencari informasi yang lebih banyak tentang seks. Sehingga ketika remaja salah memilih sumber informasi yang tidak tepat, maka remaja dapat terlibat dengan perilaku yang salah atau menyimpang.

6. Tekanan sosial-ekonomi

Dijaman serba teknologi saat ini menyebabkan permsalahan tersendiri bagi remaja. Media sosial menayangkan berbagai model peran yang dianggap menarik bagi remaja. Salam (2016), menyebutkan salah satu faktor yang memperngaruhi remaja berpenampilan urak-urakan, menggunakan gaya bahasa yang kurang santun, dan menunjukkan perilaku agresif sebagiannya dipengaruhi oleh tayangan sinetron. Hal ini disebabkan keinginan remaja untuk memiliki tokoh idola, namun kurangnya bimbingan atau dampingan orang tua dalam hal menonton tayangan yang tidak semuanya positif dan sinetron itu sendiri yang lebih banyak menampilkan konten-konten negatif.

Selain peran model yang ditampilkan media sosial Rifauddin, M. (2016) menjelaskan bagaimana perkembangan teknologi informasi, internet dan media sosial memberikan dampak perubahan kepada perilaku manusia dalam bersosial dan berkomunikasi. Komunikasi tanpa pengawasan dalam lingkup sosial akan dapat menyebabkan berbagai macam penyimpangan, sebagai contoh yang akhir-akhir ini sering kita dengar dengan istilah cyberbullying. Banyak remaja atau generasi-generasi muda saat ini yang menggunakan sosial media untuk saling berkomunikasi, seperti facebook. Tidak sedikit kasus yang pernah terjadi terhadap generasi generasi muda tersebut tentang cyberbullying. Didalam tulisannya digambakan fenomena cyberbullying terhadap para remaja di sosial media facebook beserta dengan beberapa contoh nyata yang pernah terjadi di Indonesia.

Selain pengaruh lingkungan, banyak faktor yang dapat menyebabkan kenakalan remaja. Dari beberapa teori dapat disimpulkan beberapa hal.

\section{Pilihan pribadi}

Kenakalan yang dilakukan seorang anak adalah pilihannya atau kemampuannya untuk melakukan sesuatu. Menurut Wirawan (2016) hal ini sesuai dengan yang kondisi di Indonesia, yakni kenakalan remaja dianggap sebagai 
tindakan yang didasari dengan kurangnya iman dalam diri remaja, sehingga sebagian remaja dikirim kepesantren agar memiliki keimanan yang lebih.

\section{Faktor budaya}

Yang menyebabkan kenakalan remaja adalah kurangnya atau menghilangnya kontrol dari masyarakat. Orang tua yang sibuk bekerja, dan kelebihan beban mengajar pada guru menjadi penyebab tidak berfungsinya keluarga dan sekolah sebagai kontrol masyarakat.

\section{Tekanan kehidupan}

Kemiskian menjadi salah satu penyebab remaja melakukan kejahatan, agar dapat melanjutkan hidup remaja mencuri maupun merampok. Al-Mighwar (2005) menjelaskan kondisi sosial ekonomi keluarga yang tidak memungkinkan remaja untuk memiliki simbolsimbol status sosial seperti pakaian, kendaraan, $\mathrm{Hp}$ dan sebagainya akan membuat remaja merasa minder atau rendah diri dalam pergaulan sosial.

\section{Salah bergaul}

Dari beberapa penelitian dan hasil wawancara surat kabar diatas, dapat disimpulkan bahwa pergaulan yang salah menjadi salah satu faktor penyebab kenakalan remaja. Bagaimana konformitas sangat berpengaruh pada sikap dan perilaku anak. Salah satunya penelitian dari Saputro dan Soeharto (2012) yang menunjukkan ada hubungan positif yang sangat signifikan antara konformitas terhadap teman sebaya dengan kecenderungan kenakalan pada remaja,

\section{Labelling}

Killing N dan Killing Y (2015) menilai label yang diberikan oleh orang lain, dapat mempengaruhi konsep diri pada seorang remaja. Konsep diri seseorang tergambarkan dalam halhal yang berkaitan dengan individu tersebut. Pandangan terhadap diri sendiri, hasil evaluasi diri, serta harapan terhadap diri sendiri membentuk konsep diri individu. Cap bahwa seseorang dianggap sebagai anak nakal dapat menyebabkan anak menjadi benar-benar nakal, remaja yang selalu dianggap pembuat onar akan benar-benar menjadi pembuat onar.

Kenakalan yang dilakukan para remaja pelaku klitih tidak saja kerugian secara materil namun juga inmateril. Jensen (dalam Wirawan, 2016) membagi kenakalan remaja menjadi empat jenis,yaitu: (1) Kenakalan yang menimbulkan korban fisik pada orang lain, seperti perkelahian, perkosaan, perampokan, pembunuhan dan lain-lain; (2) Kenakalan yang menimbukan korban materi, misalnya seperti pencurian, perusakan, pemcopetan dan pemerasan; (3) Kenakalan sosial yang tidak menimbulkan korban dipihak orang lain, misalnya pelacuran, penyelahgunaan obat, alkohol dan sebagainya; (4) Kenakalan yang melawan status, misalnya membolos bagi pelajar, pergi dari rumah orang tua.

\section{Konseling Eksistensial untuk Remaja}

Konseling yang dilakukan kepada remaja berbeda dengan konseling yang akan dilakukan untuk orang dewasa. Konseling pada remaja mengharuskan konselor membentuk hubungan yang lekat dengan kliennya. Kecakapan konselor dalam berbicara juga dituntut dalam konseling remaja. Selain itu terapi keluarga juga dibutuhkan untuk mengatasi masalah psikologis, perlaku dan emosional pada anak, dengan menggabungkan konseling individu dan terapi keluarga diharapkan mampu memberikan kesempatan kepada anak untuk menyelesaikan masalah pribadinya dan menyelesaikan masalah lingkungan pada anak.

Menjawab pertanyaan remaja tentang memahami dirinya, sehingga remaja dapat mengidentifikasi dirinya sendiri dapat dilakukan dengan metode konseling esistensial. Konseling eksistensial bertujuan untuk membantu sesorang memahami tentang diri sendiri dan bagaimana ia ada didunia. Sebagai manusia, makhluk hidup, manusia harus memahami dirinya sendiri, akan keberadaaanya, bertanggung jawab terhadap dirinya, dan bisa menjadi dirinya sendiri.

Pandangan eksistensial menekankan pada kebebasan manusia untuk memilih dan bertanggung jawab terhadap pilihannya. Berbagai pilihan yang ada bukanlah tidak terbatas melainkan memilih merespon stimulasi yang ada berdasarkan situasi yang dihadapinya. Remaja umumnya memiliki kesempatan untuk membuat pilihan dan menetukan keputusan dalam hidupnya, tetapi dalam batasan lingkungan sosial mereka. Menekankan kebebasan untuk memilih dalam batasan akan membantu remaja berfokus pada dirinya pada penerimaan atas tanggung jawab pribadinya. Eksistensial menekankan pada pencarian makna dalam hidup, pada penciptaan identitas pribadi seseorang, menciptakan hubungan yang bermakna dengan orang lain. 
Sehingga metode konseling eksistensial sangat cocok utnuk digunakan dalam konseling remaja, karena sesuai dengan pemikiran remaja dan mendorong remaja untuk menerima kecemasan sebagai sebuah realita dan membuat mereka bertanggung jawab atas semua keputusan yang mereka buat dalam keadaaan sadar dan penuh kebebasan realitasnya.

Tokoh Terkemuka Konseling Eksistensial adalah Irvin Yollom dan Rollo Reese May. May (dalam Olson, Matthew H dan Hergenhahn, 2013) mengkritisi pemikiran skinner dan Rogers yang hanya menekankan salah satu sisi dilema yang mengorbankan sisi lainnya. Skinner menghindari pengalaman subjektif, namun May memberikan beberapa pertanyaan, bukankah fakta bahwa manusia memang beraksi terhadap pengalaman batin lingkungan mereka, bukankah mereka melihat lingkungan berdasarkan pengalaman masa lalu mereka, dan menginterpretasikannya berdasarkan simbol, harapan, dan ketakutan mereka. Dan beberapa pertanyaan untuk Rogers, karena menekankan subjektivitas dan menghilangkan dari analisisnya komponenkomponen negatif eksistensi manusia seperti kemarahan, agresi, permusuhan dan dendam. Rogers juga dianggap terlalu menekankan rasionalitas dan keyakinannya bawa individu hanya sekedar memilih yang rasional baginya, meyisakan sebagian spektrum besar spektrum pengalaman manusia, yaitu perasaan irasional.

Konsep dasar dalam Konseling eksistensial Rollo May yaitu adanya pemahaman tentang being-non being. Being dianggap dalam bagian dari kata kerja yang diartikan sebagian seseorang sedang dalam proses menjadi sesuatu. Manusia dimaksudkan mampu mempunyai kemampuan atau kapasitas dalam dirinya untuk menjadi sesuatu, manusia dapat memilih beingnya sendiri. Sense-of being pada manusia mengacu pada seluruh pengalaman eksistensinya, baik secara sadar maupun tidak sadar.

Sedangkan non-being adalah eksistensi yang dianggap kemungkinan tersebut tidak ada. Ada sejumlah kekhawatiran atau ancaman untuk being sehingga being kehilangan potensinya untuk menyelesaikan keinginannya dan menyelesaikan kekurangan kesadarannya. Ancaman terbesar menurut May adalah kematian, hal ini dipengaruhi oleh pengalaman masa lalu May yang pernah menderita TBC diusia 30 tahun. Saat sakit ia melihat bahwa orang yang menerima penyakitnya justru lebih cepat meninggal dibanding mereka yang melawan penyakitnya.

May menggunakan istilah freud, yaitu bawah sadar, untuk menggambarkan pengalaman kognitif yang disangkal oleh kesadarannya. Penyangkalan itulah yang menimbulkan kecemasan yang terlalu besar jika dialami oleh seseorang. Eksistensial bertujuan untuk menghilangkan kecemasan neurotik dan rasa bersalah neurotik, karena kecemasan normal dan rasa bersalah normal dianggap sebagai perasaan manusia normal yang sehat. Kecemasan dan rasa bersalah dapat mengakibatkan rendahnya harga diri remaja yang dapat menjadikan remaja melakukan kenakalan untuk mengatasi stresor tersebut. Eksistensial memberikan kekuatan kepada klien, untuk memahami kejadian-kejadian yang telah dialaminya sebagai sebuah takdir, namun dengan pandangan yang berbeda. Tujuannya adalah untuk membantu klien untuk menemukan makna didalam situasi-situasi yang sebelumnya tidak bisa mereka temukan atau merasa tidak berdaya untuk menemukannya.

May menggunakan asosiasi bebas untuk mengungkap permasalahan yang dihadapi klien. May percaya setiap individu memiliki tujuan atau penemuan makna diri sendiri melalui dirinya sendiri. Manusia memiliki potensi untuk bebas dan menjalani hidup tanpa ada hambatan. May menggunakan istilah perjumpaan, untuk mendeskripsikan proses terapeutik. Perjumpaan adalah apa yang sungguh terjadi, sesuatu yang jauh lebih dari sekedar sebuah hubungan. Diperjumpaan ini konselor diharapkan mampu merasakan apa yang dialami oleh klien. Empati digunakan sebagai kunci dari konseling ini. Dengan demikian, tugas utama seorang konselor atau konselor adalah memahami pasien dalam "keberadaan" dan "ketidak beradaanya" didunia ini.

\section{Desain Konseling untuk Remaja Pelaku Klitih}

Konseling Eksistensial merupakan metode atau cara untuk melihat manusia sebagai sebuah sistem yang taat. Richard Nelson-Jones. (2011) mendeskripsikan tujuan utama konseling eksistensial adalah remaja mampu menghadapi eksistensinya sebagai suatu yang riil. Lebih spesifik, konseling eksistensial membantu remaja untuk memulai perjalanan investigasidirinya, dengan tujuan; (1) Memahami konflik tak sadarnya; (2) Mengidentifikasi mekanismemekanisme pertahanan maladaptifnya; 
Menemukan pengaruh destruktifnya; (4)

Mengurangi kecemasan sekunder dengan mengoreksi moda-moda restriktif dalam menghadapi dirinya dan orang lain; (5) Mengembangkan cara-cara lain untuk mengatasi kecemasan primer

Konseling Eksistensial membantu remaja untuk memahami konflik batinnya dalam kaitanya dengan ketakutan eksistensial mendasarnya. Konseling memfokuskan pada bagaimana remaja menghindari tanggung jawab pribadi atas penyebab stresnya. Konselor diharapkan mampu mengidentifikasi mekanisme-mekanisme pertahanan diri remaja sehingga mampu membangkitkan kesadaran tentang konsekuensi negatifnya. Konselor hendaknya juga dapat membantu remaja mengatasi kecemasan primer maupun sekunder, konselor dapat menggunakan berbagai macam intervensi lain untuk proses terapeutik selama pendekatan itu kosisten dengan kerangka dasar eksistensial.

Dalam konseling eksistensial, hubungan antara konselor dan klien merupakan hal yang utama, konselor harus menyampaikan kepada remaja bahwa tugas utamanya adalah bersamasama membangun hubungan agar tercipta suatu perubahan. Konselor eksistensial menekankan kedalaman konfrontasi dengan ketakutan mendasar, konselor mencoba menjadi klien, memahami situasi klien dengan ketakutanketakutan yang dialaminya. Konseling eksistensial bukan seorang reflektor atau cermin bayangan tetapi manusia hidup yang mencoba memahami dan mengalami being klien. Pengungkapan diri konselor adalah hal penting dalam konseling eksistensial. Konselor dapat mengungkapkan tentang pengalaman pribadinya untuk belajar menerima ketakutan-ketakutan eksistensial yang mendasar dan menjadi hal yang manusiawi. Konselor dapat menggunakan pikiran dan perasaanya tentang apa yang terjadi untuk memperbaiki hubungan konselingutiknya.

Jika konseling lain berpegang pada suatu teknik tertentu, berbeda dengan konseling eksistensial. Konseling eksistensial tidak memiliki teknik tertentu, namun teknik mengikuti pemahaman. Tugas dan tanggung jawab konselor adalah memahami klien sebagai ada dan ada didalam dunianya.

Dari beberapa teori konseling eksistensial dari para tokoh, proses intervesi atau tekonik konseling yang bisa dilakukan konselor untuk mengatasi perilaku klitih pada remaja dapat dilakukan dengan proses sebagai berikut
1. Mengindetifikasi kecemasannya atau permasalahannya

Richard Nelson-Jones ( 2011) menjelaskan untuk proses konseling pertama, konselor diharapkan mampu membimbing remaja untuk memahami permasalahan yang ada dalam dirinya, memahami seluruh konflik yang sadar maupun yang tidak sadar. Konselor memberikan kesadaran pada remaja bahwa permasalahan atau kecemasan yang ada tidak melekat pada kehidupannya namun remajalah yang bertanggung jawab untuk menciptakan kecemasan itu sendiri.

Konselor menuntun remaja menemukan permasalahan yang dihadapinya. Teknik SelfDisclousure dapat digunakan untuk membantu remaja mengidentifikasi permasalahannya. Teknik Self - Disclousure atau teknik pengungkapan diri, dijelaskan oleh Bradley $\mathrm{T}$ (2016), bahwa konselor memiliki tanggung jawab untuk memberi tahu remaja tentang pendidikan, pengalaman, latar belakang dan pendekatan konselor dan faktor lain yang menunjukkan konselor mampu menangai tujuan-tujuan dari proses konseling tersebut. Dalam eksistensial teknik self disclousure dapat dilihat sebagai memberi contoh atau mengajari remaja. Teknik self- disclousure dapat dilakukan dengan 2 cara yaitu disengaja dan tidak disengaja. Teknik seld-Disclousure yang disengaja dapat dilakukan dengan berbagi secara langsung pengalaman pribadi dengan remaja dengan tujuan menunjukkan ketulusan, autentisitas dan tujuan utamanya untuk memperkuat hubungan konselor dan remaja. Konselor juga dapat menyampaikan perasaan perasaan bangga, sedih atau transferens, konselor menyampaikan dan membandingakan pemahaman dan sudut pandangnya. Sedangkan teknik tidak sengaja, yaitu konselor dilatih untuk mampu menerima dan tidak menghakimi, sehingga seolah-olah konselor mampu terkesima dengan cerita remaja.

Analisis mimpi dapat digunakan untuk memahami konflik tak sadar dalam diri remaja, menganalisa mimpi buruk yang dialami remaja, walaupun beberapa remaja akan sulit menerima hasil analisis dari mimpi tersebut.

2. Mengidentifkasi mekanisme pertahanan egor

Setelah menemukan permasalahan yang ada, lalu konselor diharapkan mampu membantu klien untuk mengakui kenyataan keterbatasannya daripada mengingkarinya. Dengan memahami kekurangannya diharapkan 
klien dapat juga menerima konsekuensi negatif yang harus diterimanya. Konsep utama eksistensial adalah mengakui diri secara riil, menerima kenyataan yang ada dalam dirinya dengan seluruh permasalahan yang ditimbulkan, menghilangkan seluruh mekanisme pertahanan dirinya. Mekanisme pertahanan diri bukan jalan penyelesaian yang tepat untuk mengatasi permasalahan yang terjadi sehingga harus dihilangkan.

\section{Mengonfrontasi klien}

Teknik konfrontasi yang juga dikenal dengan sebutan teknik tantangan dapat digunakan untuk membantu klien menganalisis cerita mereka yang kontradiktif antara kata dan perbuatan. Bradley (2016) menjelaskan penggunaan teknik ini akan sangat efektif jika konselor mampu menggunakan dengan tepat. Kuncinya adalah dengan mendengarkan secara aktif dan membantu remaja mampu mengekspresikan sikap dan perilaku mereka, konflik interpersonal dan intrapersonal mereka dan keyakinan irasional serta mekanisme pertahanan diri yang membuat mereka terjebak dalam permasalahan mereka.

$$
\text { Richard Nelson-Jones }
$$

menjelaskan semua manusia memiliki keadaan yang tidak menyenangkan sesuai dengan keinginannanya. Konselor dapat membantu remaja dengan mengubah sikap remaja dengan menerima kondisi yang ada dan menjelaskan bahwa yang terjadi diluar dirinya tidak dapat diubah. Sehingga diharapkan remaja dapat menerima kondisinya dan dapat mengurangi rasa bersalah dalam dirinya karena merasa gagal mengaktualisasikan dirinya. Selama remaja masih berfikir atau berperilaku sesuai dengan masa lalunya, klien akan terus merasa bersalah dan tidak bisa memaafkan dirinya sendiri. Konselor diharapkan dapat membantu remaja memahami kondisinya dan memaafkan dirinya sendiri.

4. Memberikan ruang untuk berharap

Ijinkan remaja untuk dapat merasakan keinginan untuk dapat berharap, walaupun untuk mereka yang memiliki afeksi yang sudah tertutup itu akan sangat lama dan berulangulang. Caranya dengan memberdayakan remaja untuk dapat menentukan tujuannya. Richard Nelson (2012) menjelaskan ada empat cara, yaitu dengan membantu remaja memfokuskan perhatian dan tindakannya, membantu memobilitasi energi dan usaha, memberikan insentif bagi remaja untuk mencari strategistrategi untuk mencapai tujuannya, dan tujuan- tujuan yang jelas dan spesifik yang mampu membantu remaja meningkatkan persistensinya.

5. Memfasilitasi untuk memutuskan dan merancang kehidupan.

Konseling eksistensial mendorong remaja untuk melihat bahwa setiap perilaku atau tindakan selalu didasari oleh sebuah keputusan. Keputusan yang sulit dibuat karena alternatif pilihan disingkirkan. Oleh sebab itu konselor diharapkan mampu membantu klien untuk memunculkan dan mengevaluasi pilihan-pilihan keputusan. Konselor dapat membantu remaja membuat keputusan dengan memberikan kekuatan atau dorongan. Richard Nelson (2012) menjelaskan bahwa sebagai konselor, kita diharapkan mampu memfasilitasi remaja untuk memilih opsi-opsi dalam mencapai tujuanya, mendorongnya untuk spesifik tentang bagaimana ia mampu mengimplementasaikan opsi-opsi tersebut, jika perlu mengurutkan langkah demi langkah yang memiliki kerangka waktu. Lalu konselor juga diharapkan mampu mengeksplorasi komitmen remaja untuk mengimplementasikannya, termasuk bagaimana cara mengatasi kesulitan dan kemunduran yan diantisipasi.

\section{SIMPULAN DAN SARAN}

Perilaku klitih yang dilakukan oleh remaja tidak saja merugikan secara materiil namun juga inmateriil. Masa depan remaja dipertaruhkan disini, Sehingga dibutuhkan penanganan yang tepat agar remaja tidak lebih jauh menghadapi seluruh permasalahan yang ada. Dengan metode konseling eksistensial remaja dapat mengeksplorasi kemampuan yang dimilikinya, memahami tentang diri sendiri dan bagaimana ia ada didunia. Pandangan eksistensial yang menekankan pada kebebasan manusia untuk memilih dan bertanggung jawab terhadap pilihannya membuat remaja memiliki kesempatan untuk membuat pilihan dan menetukan keputusan dalam hidupnya. Dengan tetap menekankan batasan untuk membantu remaja berfokus pada dirinya pada penerimaan atas tanggung jawab pribadinya. Sehingga remaja dapat mencari makna dalam hidup, menciptakan identitas pribadiya, dan menciptakan hubungan yang bermakna dengan orang lain.

Pada penelitian selanjutnya peneliti menyarankan untuk penerapkan konseling eksistensial kepada remaja pelaku klitih, sehingga penelitian ini dapat lebih berkembang. 
Teknik atau intervensi yang lain juga dapat dikembangkan.

\section{DAFTAR PUSTAKA}

Abidin, Zainal. (2007). Analisis Eksistensial, Sebuah Pendekatan Alternatif untuk Psikologi dan Psikiatri. Jakarta; Rajagrafindo

Al-Mighwar, Muhammad. (2005). Psikologi Remaja; Petunjuk bagi Guru dan Orang tua. Bandung; Pustaka Setia

Bradlety T. Eriord. (2016). 40 Teknik yang Harus Diketahui setiap Konselor. Terjemahan: Helly Prajitno Suoetjipto dan Sri Mulyantini Soetjipto. Yogyakarta: Pustaka Pelajar

Rifauddin, Machsun .(2016). Fenomena Cyberbullying pada Remaja. (Studi Analisis Media Sosial Facebook). KHIZANAH AL-HIKMAH Vol. 4 No. 1, Januari - Juni 2016

Geldard, Kathryn dan David Geldard. (2011). Konseling Remaja; Pendekatan Proaktif untuk Anak Muda. Terjemahan; Eka Adinugraha. Yogyakarta; Pustaka Pelajar

Hidayati, Novi Wahyu. (2016). Hubungan Harga Diri dan Konsformitas Teman Sebaya dengan Kenakalan Remaja. Jurnal Penelitian Pendidikan Indonesia (JPPI); Vol. 1, No. 2, April 2016

Hidayat, Dede Rahmat. 2011 Teori dan Aplikasi; Psikologi Kepribadian dalan Konseling. Bogor; Ghalia Indonesia. hal 197- 199

Lakukan Aksi Klitih Lima Kali dalam Waktu Semalam Empat Pemuda di Sleman diciduk Polisi. (2019). Diakses melalui http//jogja.tribunnews.com/2019/01/04/1 akukan-aksi-klitih-lima-kali-dalamwaktu-semalam-empat-pemudadiSleman-diciduk-polisi.

Mantiri, Gabriella Prillycia dan Andriani, Fitri.(2012). Pengaruh Konformitas dan Persepsi Mengenai Pola Asuh Otoriter Orang Tua terhadap Kenakalan Remaja (Juvenile Deliquency) (Abstrak). Jurnal Psikologi Pendidikan dan Perkembangan: Volume : 1 - No. 2 Terbit : 6--2012
Nindya P. N dan Margaretha R. (2012).Hubungan antara Kekerasan Emosional pada Anak terhadap Kecenderungan Kenakalan Remaja. Jurnal Psikologi Klinis dan Kesehatan Mental Vol.1.No.02.,Juni 2012

Novianti, Abdul Munir dan Munifah. (2017). Hubungan antara Perilaku Konformitas Negatif Teman Sebaya dengan Kenakalan Remaja Siswa Kelas XI SMA N 1 Sindue. Jurnal Konseling \& Psikoedukasi Volume 2, Nomor 2, Desember 2017. Hal. 63 - 74

Pengakuan Mantan Pelajar Pelaku Klitih diYogyakarta. (2018) Diakses melalui https://m.merdeka.com/amp/peristiwa/p engakuan-mantan-pelajar-pelaku-klitihdi-Yogyakarta. tanggal 30 Desember $\underline{2018}$

Prayugo, M.Inggit, Suroso dan Meiyutaringsih, Tatik (2018). Hubungan Konsep Diri dan Konformitas Teman Sebaya dengan Perilaku Agresif Remaja (Studi Korelasi pada Siswa XI SMK Krian 2 Sidoarjo. Psikosains; Vol 13 No 1. Februari 2018,

Olson, Matthew H dan Hergenhahn.(2013). Pengantar Teori-teori Kepribadian, terjemahan. Yogyakarta; Pustaka Belajar. hal 890

Richard Nelson-Jones.(2011a). Teori dan Praktik Konseling dan Konseling Terjemahan oleh Helly Prajitno Suoetjipto dan Sri Mulyantini Soetjipto. Yogayakarta; Pustaka Pelajar. hal 321

Richard Nelson-Jones.(2012b). Pengantar Keterampilan Konseling. Terjemahan; Helly Prajitno Soetjipto dan Sri Mulyantiin Soetjipto. Prajitno Soetjipto dan Sri Mulyantiin Soetjipto. Yogyakarta; Pustaka Pelajar

Salam, Ahmad Muhyi. (2016). Pengaruh Sinetron "Anak Jalanan" terhadap Perilaku Remaja di Kota Samarinda. Lentera; Vol. XVIII, No. 2, 2016

Santrock, John W. (2007). Remaja. Terjemahan; Benedictine Widyasinta. Editor; Wibi Hardani. Jakarta; Erlangga

Saputro, Bayu Mardi dan Soeharto, Triana N E D. (2012). Hubungan antara Konformitas terhadap Teman Sebaya dengan Kecenderungan Kenakalan pada 
27 | JURKAM: Jurnal Konseling Andi Matappa Vol 4, No 1, Februari 2020

Remaja. INSIGHT Volume 10, Nomor 1, Februari 2012

Selama 201813 Kasus Klitih Terjadi di Yogyakarta Dua korban Meninggal Dunia. (2018). Diakses melalui http://jogja.tribunnews.com/2018/12/27/ selama-2018-13-kasus-klitih-terjadi-diYogyakarta-dua-korban-meninggaldunia

Wirawan, Sarlito Sarwono. (2016). Psikologi Remaja. Depok; Rajagrafindo Persada. 